\title{
Effect of storage temperature on physicochemical quality attributes of fresh Bombay red onion bulb (Allium cepal L.)
}

\author{
Ayalew Demissew \\ Email: ayalewdemissew@yahoo.com, \\ Amhara Regional Agricultural Research Institute \\ Email: arari@ethionet.et \\ Bahir Dar Food Science and Postharvest Handling Research Center \\ P.o.box 794, Cell phone +251912604705
}

\begin{abstract}
Onion (Allium cepal L.) is a major commercial vegetable crop grown in almost all parts of the world. In Ethiopian the postharvest loss of onion bulb crop was estimated to be $50 \%$ during the production season. So to reduce this postharvest loss of onion bulb determining and employing appropriate storage conditions play an important role. Appropriate storage condition reduces the physiological quality which intern reduces the physicochemical and phytochemical properties of onion. In this study physicochemical and phytochemical properties of onion bulb were investigated under different storage temperature. Onion bulbs were stored at three different temperatures the following quality attributes of onion bulb like glucosidase content, pyruvic acid, flavonoid, dry matter and sugar content were determined for storage period of six months. Quality deterioration of onion bulb was higher at storage temperature of $25^{\circ} \mathrm{C}$ while storage temperature $5^{\circ} \mathrm{C}$ was found an ideal condition with keeping the quality of onion bulb acceptable. In all the three storage temperatures sugar content show pyruvic acid, glucosidase and sugar content show irregular pattern. Bombay red onion bulb was stored for six months without significant change of quality attributes of onion bulb at storage temperature of $5^{\circ} \mathrm{C}$.
\end{abstract}

Keywords: Onion bulb, sugars, pungency and peroxidase activity 


\section{Introduction}

Onion (Allium cepal L.) is one of the major commercial vegetable crops grown in most parts of the world including Ethiopia their flavor attributes. Now a day's onion bulb is becoming parts of daily diet all round the year (Endalew, W., et.al, 2015). In Ethiopian mostly the fresh onion bulb was used for preparation of traditional foods and in some part the shredded onion bulb was mixed with other spices so that it will be used for several purposes (Ayalew, D., et.al, 2017). Onion bulb is also becoming an important commercial crop for small holder farmers in Ethiopia (Fekadu M and Dandena G., 2006).

Onion bulb is naturally perishable in nature due to having high moisture content. Different onion bulb varieties need different conducive storage temperatures like some needs $0-5^{\circ} \mathrm{c}$ while others need $25-30^{\circ} \mathrm{c}$ at an average relative humidity of $65 \%$ (.Milenkovic, I.Z., et.al, 2009). Major storage postharvest loss of onion bulb was physicochemical and phyto-chemical attributes and bulb sprouting and rooting. Among all, bulb sprouting and rooting postharvest loss of onion bulbs accounts 46 to $56 \%$ under different storage condition of different storage structure (Kukanoor, L. 2005). Major external factors for onion bulb postharvest loss are temperature, relative humidity, harvesting condition, light, pretreatments and maturity the bulb while the internal factors physiological and metabolic activity of onion bulbs (Biswas S.K., et.al, 2010). In Ethiopia onion bulbs are stored using different naturally ventilated storage structure or simply heaping the onion bulbs directly on the floor at room temperature (Endalew, W., et.al, 2015). During storage period sprouting is a critical physiological factor which restricts the storability of onion bulb. The storage environment of storage structures employed in storing onion bulb plays pertinent role in keeping the all physicochemical attributes of onion bulb. Storage temperature plays critical role from the rest of storage conditions in influencing the quality attributes of onion which actually the exact conducive temperature depend on onion variety (Miedema P., 1994). The effect of different storage temperature on physicochemical property of Bombay red onion cultivar along the storage period was not evaluated and reported. Therefore five different temperature storage temperatures were selected based on literature and local trends. Then different physicochemical quality attributes of onion bulb were determined during storage period of six months. 


\section{Materials and Methods}

\section{Chemicals and standard solutions}

Bombay red onion bulb was collected from Koga experimental site of Adet agricultural research center in Amhara regional state, Ethiopia. The onion harvested when matured and cured there for 8 days. Then it was trimmed of the leaves and roots. The storage experiment was conducted at controlled condition $\left(5^{\circ} \mathrm{C}, 10^{\circ} \mathrm{C}, 15^{\circ} \mathrm{C}, 20^{\circ} \mathrm{C}, 25^{\circ} \mathrm{C}\right.$ and relative humidity of $\left.75 \%\right)$. Onion bulb of $250 \mathrm{Kg}$ was weighed and stored at five different storage temperatures by weighing $50 \mathrm{Kg}$ for each storage condition. The bulbs were placed on stainless steel trays. During the experiment eight onion bulbs were randomly selected for analysis up to the six month where sprouting appears starting from the first day and then within an interval of a month. During sampling each bulb was cleaned and chopped into small parts and then mixed well to get the representative parts of the whole onion bulb.

\section{Characterization of onion bulb}

Dry matter content: The dry matter content in onion bulbs was determined by drying chopped samples of $30 \mathrm{~g}$ according (AOAC, 1995).

Peroxidase activity: The peroxidase activity was determined according to the method by (Gủnes B and Bayindirh A., 1993.).

Analysis of sugar content: Sugar contents of onion bulbs were determined according to a method followed by (Kahane R., 2001).

Analysis pyruvic acid: Pyruvic acid content was analyzed a method followed by (Abayomi LA and Terry LA., 2009).

\section{Statistical analysis}

All the results in the table below are means \pm standard deviations of triplicates of samples during the experiment. The data's were analyzed statistically by ANOVA at $(\mathrm{p}<0.05)$. 


\section{Result and discussion}

In conducting effect of storage temperature on physicochemical quality attributes of onion bulb along a storage period Bombay red onion bulb was chosen because of its high productivity in Amhara region, Ethiopia. During the experimental period inner sprouting was detected by longitudinally cut of onion bulbs along a storage period within time interval of one month in the three storage temperatures. In the present study visible sprouting was found at different time intervals. Sprouting appeared visibly at five month in storage temperature of $5^{\circ} \mathrm{C}$ and $25^{\circ} \mathrm{C}$. For a storage temperature of $10^{\circ} \mathrm{C}$ and the rest two storage temperatures sprouting seen starting from the fourth month. Although sprouting were less in storage temperature of $25^{\circ} \mathrm{C}$ other basic quality parameters of onion bulb were not found acceptable. The result found during storage experiment concerning about sprouting does not agree with the result fond and reported by (Ward CM., 1976) where he reported late sprouting of onion bulb for storage temperature of $25^{\circ} \mathrm{C}$. High quality attribute loss onion bulbs at storage temperature of $25^{\circ} \mathrm{C}$ were found during the experiment where the result obtained coincides with the result determined and reported by (Ward CM., 1976, Uddin M and MacTavish HS., 2003 and Sharma K., et.al, 2015).

Weight loss and dry matter content: The dry matter of Bombay red onion Bulb indicates that onion contains $86.60 \%$ of volatile compounds, which largely includes water. The dry matter content found in this experiment was similar with the results found and reported by (Endalew, W., et.al, 2015 and Ayalew, D., et.al, 2017) for identical onion cultivar. Storage temperature is critical factor which influence the weight loss and dry matter content of onion bulb during storage. When onion is stored weight loss occurred due to the action of desiccation, respiration and sprouting. These entire phenomenons are directly related with storage temperature to mean that the higher the storage temperature the greater the weight loss. In the experiment greater weight loss was found at a storage temperature of $25^{\circ} \mathrm{C}$ which was $21.8 \%$. In contrast to my result obtained (Kamerbee GA., 1962) determined and reported minimal weight loss of $6 \%$ to $14 \%$ of the fresh weight at storage temperature of $25^{\circ} \mathrm{C}$. Higher storage temperature increases water activity and reaction rate which finally negatively affect quality of onion bulbs. The dry matter content of onion bulb stored at $5^{\circ} \mathrm{C}$ was found nearly constant up to the $5^{\text {th }}$ months but the dry matter content of onion bulb reduce significantly for the rest storage temperatures. The results obtained were completely different than the result found and reported in (Miedema P., 
1994). Storage temperature affects degradation of onion bulb organic matter and the processes of conversion of organic substances in to volatile compounds through dormancy break and sprouting (Yasin HJ and Bufler G., 2007).

Table-1: Changes in DM of onion bulb in as storage temperature of $5^{\circ} \mathrm{C}, 10^{\circ} \mathrm{C}, 15^{\circ} \mathrm{C}, 20^{\circ} \mathrm{C}$ and $25^{\circ} \mathrm{C}$

\begin{tabular}{|c|c|c|c|c|c|}
\hline Storage time (Months) & s) $\mathrm{DM}(\%)$ at $5^{\circ} \mathrm{c}$ & $\mathrm{DM}(\%)$ at $10^{\circ} \mathrm{C}$ & $\mathrm{DM}(\%)$ at $15^{\circ} \mathrm{C}$ & $\mathrm{DM}(\%)$ at $20^{\circ} \mathrm{c}$ & $\mathrm{DM}(\%)$ at $25^{\circ} \mathrm{c}$ \\
\hline 0 & $14.28 \pm 1.09^{\mathrm{a}}$ & $14.25 \pm 1.09^{b}$ & $14.28 \pm 1.20^{\mathrm{ac}}$ & $14.28 \pm 1.20^{\mathrm{ad}}$ & $14.28 \pm 2.10^{\mathrm{ec}}$ \\
\hline 1 & $15.34 \pm 0.92^{\mathrm{a}}$ & $15.02 \pm 0.92^{\mathrm{b}}$ & $15.00 \pm 0.89^{\text {ace }}$ & $14.98 \pm 0.92^{\text {aa }}$ & $14.87 \pm 1.32^{\mathrm{ea}}$ \\
\hline 2 & $16.07 \pm 0.03^{\mathrm{a}}$ & $16.01 \pm 1.00^{\mathrm{b}}$ & $15.8 \pm 0.16 \mathrm{a}^{\mathrm{edc}}$ & $15.05 \pm 1.50^{\mathrm{dac}}$ & $15.32 \pm 0.98^{\mathrm{ec}}$ \\
\hline 3 & $15.65 \pm 1.20^{\mathrm{a}}$ & $13.46 \pm 2.30^{\mathrm{b}}$ & $15.7 \pm 1.20^{\text {cde }}$ & $15.23 \pm 2.50^{\mathrm{dba}}$ & $15.21 \pm 1.32^{\text {eda }}$ \\
\hline 4 & $14.59 \pm 1.50^{\mathrm{a}}$ & $12.99 \pm 1.30^{\mathrm{b}}$ & $14.3 \pm 1.80 \mathrm{c}^{\mathrm{ed}}$ & $14.12 \pm 0.98^{\mathrm{dba}}$ & $12.78 \pm 1.32^{\mathrm{edc}}$ \\
\hline 5 & $14.48 \pm 1.20^{\mathrm{a}}$ & $14.33 \pm 1.20^{\mathrm{b}}$ & $13.5 \pm 2.50^{\text {cda }}$ & $13.89 \pm 1.20^{\mathrm{dca}}$ & $12.56 \pm 3.21^{\text {eda }}$ \\
\hline 6 & $14.18 \pm 0.93^{\mathrm{a}}$ & $13.09 \pm 0.89^{\mathrm{b}}$ & $12.6 \pm 2.50^{\text {eda }}$ & $13.57 \pm 1.20^{\text {dea }}$ & $13.42 \pm 1.56^{\mathrm{ec}}$ \\
\hline
\end{tabular}

*Values are mean \pm standard deviations of triplicate and Values followed by the same letters in the same row are not significantly different $(p<0.05)$.

Peroxidase activity: The enzyme peroxidase involves in oxidation of flavonoids. For the first four month's storage period at all storage temperatures peroxidase activity increases but with different ways. Maximum increment of peroxidase activity was found at $25^{\circ} \mathrm{C}$ which was 140 units/100g. The result obtained in this experiment contradicts with the report by (Benkeblia $\mathrm{N}$ and Selselet-Attou G., 1999) which was $140 \mathrm{units} / 100 \mathrm{~g}$ at a temperature of $0-5^{\circ} \mathrm{C}$. The reason for such complete contradiction may arise the difference in onion cultivar. As it was seen from table2 below at $5^{\circ} \mathrm{c}$ peroxidase activity incrase upto $140 \mathrm{units} / 100 \mathrm{~g}$ in the first three months and then reduced and finally become constant at $120 \mathrm{units} / 100 \mathrm{~g}$ for the last two months. Peroxidase activity in at low storage temperature was found less significant while sprouting aggravates increment of peroxidase activity of onion bulb. Similar result was found and reported by (Benkeblia N., et.al, 2004). An increase in peroxidase activity facilitates quercetun oxidation and forms new compounds which are basically indices of sprouting of onion bulbs. 
Table-2: Peroxidase activity (units/ $100 \mathrm{~g} \mathrm{FW}$ ) in onion bulb at storage temperature of $5^{\circ} \mathrm{C}, 10^{\circ} \mathrm{C}$, $15^{\circ} \mathrm{C}, 20^{\circ} \mathrm{C}$ and $25^{\circ} \mathrm{C}$ along storage months

\begin{tabular}{|c|c|c|c|c|c|c|c|}
\hline & 0 & 1 & 2 & 3 & 4 & 5 & 6 \\
\hline 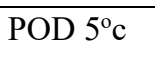 & $100.0 \pm 5.1$ & $115 \pm 7.1$ & $132 \pm 7.1$ & $140 \pm 6.5$ & $135 \pm 6.8$ & $120 \pm 8.7$ & $120 \pm 8.7$ \\
\hline POD $10^{\circ} \mathrm{c}$ & $100.0 \pm 5.2$ & $120 \pm 6.3$ & $125 \pm 6.0$ & $135 \pm 4.8$ & $125 \pm 6.22$ & $125 \pm 8.7$ & $125 \pm 5.6$ \\
\hline POD $15^{\circ} \mathrm{c}$ & $100 \pm 4.2$ & $125 \pm 3.2$ & $128 \pm 4.2$ & $132 \pm 2.8$ & $122 \pm 5.1$ & $115 \pm 3.1$ & $112 \pm 5.0$ \\
\hline POD $20^{\circ} \mathrm{c}$ & $100 \pm 2.8$ & $131 \pm 3.0$ & $135 \pm 4.7$ & $136 \pm 1.9$ & $124 \pm 2.5$ & $112 \pm 6.1$ & $110 \pm 3.0$ \\
\hline POD $25^{\circ} \mathrm{c}$ & $100.0 \pm 5.3$ & $140 \pm 5.8$ & $150 \pm 6.9$ & $140 \pm 5.7$ & $120 \pm 6.7$ & $110 \pm 2.44$ & $110 \pm 6.5$ \\
\hline
\end{tabular}

*Values are mean \pm standard deviations of triplicate

Sugar content: In six month storage period with five different storage temperature sugar content changes differently. At $5^{\circ} \mathrm{C}$ and $10^{\circ} \mathrm{C}$ storage temperature sugar content of onion bulb changes with similar pattern while the rest three storage temperature the pattern of sugar content of onion bulb were different. Initially during the $1^{\text {st }}$ month, sugar content increased and then consistent reduction was observed in the following months. Sucrose content was found greater in the stored onion bulb than the fresh at all storage temperatures of the experiment. Similar result was found and reported by (Salamal AM., et.al, 1990). Fructose and glucose content of stored onion bulb was found nearly reduced by half from the first to sixth months of storage as it is seen the table-3 below for a storage temperature of $5^{\circ} \mathrm{C}, 10^{\circ} \mathrm{C}$ and $15^{\circ} \mathrm{C}$. In the case of $20^{\circ} \mathrm{C}$ and $25^{\circ} \mathrm{C}$ storage temperature the glucose of onion bulb increased during $3^{\text {rd }}$ to $5^{\text {th }}$ months and finally decreased but the fructose content decreases starting from the $2^{\text {nd }}$ months. Contradicting result was found reported by (Rutherford PP and Whittle R. 1982.) which states as the total sugar content remained astonishingly constant throughout the storage period. Similar fluctuation of sugar contents were found and reported by (Hurst WC., et.al, 1985). Sprouting was the cause of continuous decrement in fructose and glucose contents at $5^{\circ} \mathrm{C}, 10^{\circ} \mathrm{C}$ and $15^{\circ} \mathrm{C}$. At storage temperature of $20^{\circ} \mathrm{C}$ and $25^{\circ} \mathrm{C}$ the pattern for the sugar content was different and very less sprouted bulbs were found till the end of the storage. An increase in the concentration of glucose and fructose directly related with the commencement of sprouting as it was stated by (Benkeblia $\mathrm{N}$ and Selselet-Attou G. 1999). In our study, the concentration of fructose and glucose decreased during the internal sprouting at $5^{\circ} \mathrm{C}, 10^{\circ} \mathrm{C}$ and $15^{\circ} \mathrm{C}$. 
The reason of such decrement may be due to sprouting after 4 months of storage. Possibilities for decreamnt of concentration of sugar are related with sprout length where sugars were aggressively metabolized to give energy for the growth of the sprout as it was elaborated by (Chope GA., et.al, 2007). The variation for sugar concentration change does not only depend on sprouting but also influenced by the following factors such as variety, initial sugar content and the dormancy release time.

Table-3: Sugar content $(\mu \mathrm{mol} / \mathrm{g})$ in onion bulb storage temperature of $5^{\circ} \mathrm{C}, 10^{\circ} \mathrm{C}, 15^{\circ} \mathrm{C}, 20^{\circ} \mathrm{C}$ and $25^{\circ} \mathrm{C}$

0

1

2

3

4

5

6

\begin{tabular}{|c|c|c|c|c|c|c|c|}
\hline \multicolumn{8}{|c|}{ Sugars $5^{\circ} \mathrm{c}$} \\
\hline Fructose & $0.21 \pm 0.01$ & $0.25 \pm 0.02$ & $0.18 \pm 0.03$ & $0.29 \pm 0.02$ & $0.25 \pm 0.01$ & $0.20 \pm 0.02$ & $0.16 \pm 0.05$ \\
\hline Glucose & $0.31 \pm 0.01$ & $0.39 \pm 0.06$ & $0.36 \pm 0.09$ & $0.36 \pm 0.09$ & $0.32 \pm 0.01$ & $0.21 \pm 0.02$ & $0.19 \pm 0.01$ \\
\hline Sucrose & $0.16 \pm 0.01$ & $0.16 \pm 0.02$ & $0.16 \pm 0.02$ & $0.12 \pm 0.03$ & $0.10 \pm 0.09$ & $0.09 \pm 0.02$ & $0.09 \pm 0.03$ \\
\hline \multicolumn{8}{|c|}{ Sugars $10^{\circ} \mathrm{c}$} \\
\hline Fructose & $0.21 \pm 0.01$ & $0.26 \pm 0.02$ & $0.19 \pm 0.02$ & $0.16 \pm 0.03$ & $0.13 \pm 0.05$ & $0.11 \pm 0.01$ & $0.10 \pm 0.07$ \\
\hline Glucose & $0.31 \pm 0.01$ & $0.33 \pm 0.13$ & $0.29 \pm 0.13$ & $0.20 \pm 0.00$ & $0.12 \pm 0.01$ & $0.10 \pm 0.06$ & $0.08 \pm 0.01$ \\
\hline Sucrose & $0.16 \pm 0.00$ & $0.19 \pm 0.15$ & $0.17 \pm 0.13$ & $0.130 \pm 0.03$ & $0.11 \pm 0.01$ & $0.10 \pm 0.09$ & $0.09 \pm 0.07$ \\
\hline \multicolumn{8}{|c|}{ Sugars $15^{\circ} \mathrm{c}$} \\
\hline Fructose & $0.21 \pm 0.01$ & $0.24 \pm 0.01$ & $0.18 \pm 0.12$ & $0.14 \pm 0.03$ & $0.12 \pm 0.01$ & $0.10 \pm 0.05$ & $0.08 \pm 0.02$ \\
\hline Glucose & $0.31 \pm 0.01$ & $0.31 \pm 0.03$ & $0.27 \pm 0.03$ & $0.21 \pm 0.13$ & $0.15 \pm 0.01$ & $0.11 \pm 0.12$ & $0.07 \pm 0.01$ \\
\hline Sucrose & $0.16 \pm 0.00$ & $0.18 \pm 0.02$ & $0.17 \pm 0.01$ & $0.15 \pm 0.02$ & $0.12 \pm 0.12$ & $0.11 \pm 0.08$ & $8 \quad 0.09 \pm 0.01$ \\
\hline \multicolumn{8}{|c|}{ Sugars $20^{\circ} \mathrm{c}$} \\
\hline Fructose & $0.21 \pm 0.01$ & $0.17 \pm 0.02$ & $0.16 \pm 0.01$ & $0.13 \pm 0.01$ & $0.10 \pm 0.01$ & $0.08 \pm 0.05$ & $0.06 \pm 0.02$ \\
\hline Glucose & $0.31 \pm 0.01$ & $0.25 \pm 0.01$ & $0.26 \pm 0.00$ & $0.24 \pm 0.03$ & $0.23 \pm 0.06$ & $0.20 \pm 0.01$ & $0.17 \pm 0.07$ \\
\hline Sucrose & $0.16 \pm 0.00$ & $0.17 \pm 0.09$ & $0.19 \pm 0.07$ & $0.17 \pm 0.00$ & $0.15 \pm 0.02$ & $0.13 \pm 0.06$ & $0.10 \pm 0.03$ \\
\hline \multicolumn{8}{|c|}{ Sugars $25^{\circ}$} \\
\hline Fructose & $0.21 \pm 0.01$ & $0.19 \pm 0.03$ & $0.15 \pm 0.13$ & $0.10 \pm 0.00$ & $0.08 \pm 0.01$ & $0.06 \pm 0.06$ & $0.05 \pm 0.01$ \\
\hline Glucose & $0.31 \pm 0.01$ & $0.28 \pm 0.03$ & $0.29 \pm 0.13$ & $0.27 \pm 0.01$ & $0.27 \pm 0.02$ & $0.23 \pm 0.07$ & $0.21 \pm 0.05$ \\
\hline Sucrose & $0.16 \pm 0.00$ & $0.17 \pm 0.12$ & $0.18 \pm 0.14$ & $0.19 \pm 0.01$ & $0.14 \pm 0.01$ & $0.14 \pm 0.06$ & $0.13 \pm 0.01$ \\
\hline
\end{tabular}

*Values are mean \pm standard deviations of triplicate 
Pyruvic acid: During onion bulb storage its pungency is correlated with breakage of dormancy. The experimental data for pyruvic acid content as shown in the table-3 below changed significantly in all storage temperatures. The greatest increase of pyruvic acid was seen at $10^{\circ} \mathrm{C}$ and $15^{\circ} \mathrm{C}$ followed by $20^{\circ} \mathrm{C}$ and $25^{\circ} \mathrm{C}$. Minimal increment of pyruvic acid content was found at storage temperature $5^{\circ} \mathrm{C}$. The finding of the experiment was similar with the result reported in (Uddin M and MacTavish HS., 2003). Pyruvic acid content change of onion bulb showed a similar pattern at $10^{\circ} \mathrm{C}$ and $15^{\circ} \mathrm{C}$ for the first 2 months and increased to 42 and $52.5 \mu \mathrm{mol} / \mathrm{g}$ of fresh weight (FW), followed by a decrease of 32.6 and $38.5 \mu \mathrm{mol} / \mathrm{g} \mathrm{FW}$, correspondingly. Pyruvic acid concentration increased with respect to the fresh sample during the storage in all storage temperatures. Similar result was also reported by (Uddin M and MacTavish HS., 2003).

Pyruvic acid content in onion bulb influenced by the following factors such as dry matter, sugar content, cultivars, maturity and sulphur nutrition but during storage, the pyruvic acid content differs with changes of dry matter which is prejudiced by weight loss and dehydration of tissues. This may be the main reason for increment of pyruvic acid content during onion bulb long term storage. Dormancy breakage the flavor precursor decreased and the pyruvic acid stable product of the flavor precursor and is bulb pungency pointer. In this study, the increase pyruvic acid was observed before sprouting at $5^{\circ} \mathrm{C}$ and $10^{\circ} \mathrm{C}$ storage temperature. Contradicting result was reported in (Randle WM, and Bussard ML., 1993).

Table-4: Pyruvic acid content ( $\mu \mathrm{mol} / \mathrm{g}$ ) in onion bulb storage temperature of $5^{\circ} \mathrm{C}, 10^{\circ} \mathrm{C}, 15^{\circ} \mathrm{C}$, $20^{\circ} \mathrm{c}$ and $25^{\circ} \mathrm{C}$.

\begin{tabular}{lccccccc}
\hline & 0 & 1 & 2 & 3 & 4 & 5 & 6 \\
\hline Pyruvic $5{ }^{\circ} \mathrm{c}$ & $22.40 \pm 2.4$ & $42.2 \pm 8.5$ & $32.2 \pm 1.2$ & $32.6 \pm 1.8$ & $38.5 \pm 2.1$ & $28.8 \pm 2.6$ & $28.3 \pm 1.9$ \\
Pyruvic $10^{\circ} \mathrm{c}$ & $22.40 \pm 2.4$ & $52.5 \pm 6.3$ & $38.5 \pm 2.3$ & $33.6 \pm 2.1$ & $36.7 \pm 1.9$ & $30.9 \pm 2.1$ & $31.0 \pm 1.9$ \\
Pyruvic $15^{\circ} \mathrm{c}$ & $22.40 \pm 2.3$ & $46.3 \pm 3.2$ & $47.1 \pm 2.8$ & $38.9 \pm 5.3$ & $34.7 \pm 1.8$ & $33.8 \pm 2.3$ & $32.0 \pm 2.1$ \\
Pyruvic $20^{\circ} \mathrm{c}$ & $22.40 \pm 2.4$ & $47.6 \pm 4.5$ & $49.5 \pm 1.8$ & $40.2 \pm 1.2$ & $38.3 \pm 3.7$ & $35.3 \pm 1.6$ & $32.2 \pm 1.9$ \\
Pyruvic $25^{\circ} \mathrm{c}$ & $22.40 \pm 2.4$ & $30.3 \pm 1.3$ & $40.2 \pm 1.7$ & $33.4 \pm 1.7$ & $35.6 \pm 2.3$ & $34.2 \pm 1.2$ & $32.8 \pm 2.3$ \\
\hline
\end{tabular}

*Values are mean \pm standard deviations of triplicate 


\section{Conclusion}

It is possible to conclude that sprouting and re-growth stage fluctuate at different storage temperatures of onion bulbs. According to storage temperature of onion bulbs, sprouting phase lead to sluggish decrease in chemical composition of onion bulbs which finally reduce dry matter content, sugar and pyruvic acid content. During storage quercetin and glucosides augmented but with some variation. This increment does not directly related to enzymatic activity. Browning of onion bulb outer cover s during storage is caused by the autoxidation of quercetin glucosides, after their deglucosylation. During storage of onion bulb at a given storage temperature peroxidase activity enhaces quercetin and storage temperature is crucial factor which influence sprouting phase and other onion bulb quality attributes. From this experimental result we found storage temperature and time directly influence the biochemical quality attributes of the onion bulbs. Storage of onion bulb at lower temperature enhances shelf-life onion and accordingly, minimal pyruvic acid content. The consumption of pyruvic acids as a metabolic substrate of respiration is related to reduction in pungency of onion bulbs over the storage period.

\section{Reference}

1. Abayomi LA, Terry LA. (2009). Implicatins of spatial and temporal changes in concentration of pyruvate and glucose in onion (Allium cepa L.) bulbs during controlled atmosphere storage. $\mathrm{J}$ Sci Food Agr 89:683-687.

2. Ayalew D, Ayenew M, Mehiret M. (2017). Testing and Demonstration of Onion Flake Processing Technology in Fogera Area at Rib and Megech River Project. J Food Process Technol 8: 677. doi: 10.4172/2157-7110.1000677.

3. AOAC. (1995). Official Method of Analysis Association of Official Analytical Chemists, Virginia. $15^{\text {th }}$ Edition. Vol.2.

4. Benkeblia N, Onodera S, Yoshihira T, Kosaka S, Shiomi N.(2004). Effect of temperature on soluble invertase activity, and glucose, fructose and sucrose status of onion bulbs (Allium cepa) in store. Int J Food Sci Nutr 55:325-331. 
5. Benkeblia N, Selselet-Attou G.(1999). Effects of low temperatures on the changes in oligosaccharides, phenolics and peroxidase in inner bud of onion (Allium cepa L.) during break of dormancy. Acta Agric Scand Sect B Soil Plant Sci 49:98-10.

6. Biswas S.K., A. Khair, P.K. Sarker and M.S. Alom. (2010). Yield and storability of onion (Allium cepa L.) as affected by varying level of irrigation. Bangladesh J. Agril. Res., 35(2): 247255.

7. Bonaccorsi P, Caristi C, Gargiulli C, Leuzzi U. (2005). Flavonol glucoside profile of southern italian red onion (Allium cepa L.). J Agric Food Chem 53:2733-2740.

8. Chope GA, Terry LT, White PJ. (2007). The effect of 1-methylcyclopropene (1-MCP) on the physical and biochemical characteristics of onion cv. SS1 bulbs during storage. Postharvest Biol Technol 44:131-140.

9. Darbyshire B, Henry RJ. (1979). The associations of fructans with high percentage dry weight in onion cultivars suitable for dehydrating. J Sci Food Agric 30:1035-1038

10. Dhumal K, Datir S, Pandey R. (2007). Assessment of bulb pungency level in different Indian cultivars of onion (Allium cepa L.). Food Chem 100:1328-1330

11. Endalew, W., A. Getahun, A. Demissew, and T. Ambaye. (2014). Storage performance of naturally ventilated structure for bulb onion. Agric Eng Int: CIGR Journal, 16(3): 97-101.

12. Fekadu M, Dandena G. (2006) Review of the status of vegetable crops production and marketing in Ethiopia. Uganda J Agric Sci 12: 26-30.

13. Gủnes B, Bayindirh A. (1993). Peroxidase and lipoxigenase inactivation during blanching of green beans, green peas and carrots. LebensmWis U Technol 26:406-410.

14. Hansen SL. (1999). Content and composition of dry matter in onion (Allium cepa L.) as influenced by developmental stage at time of harvest and long-term storage. Acta Agric Scand Sect B Soil Plant Sci 49(2):103-109.

15. Hurst WC, Shewfelt RL, Schuler GA. (1985). Shelf-life and quality changes in summer storage onions (Allium cepa). J Food Sci 50:761-763. 
16. Kaack K, Christensen LP, Hansen SL, Grevsen K. (2004). Non-structural carbohydrates in processed soft fried onion (Allium cepa L.). Eur Food Res Technol 218:372-379.

17. Kamerbee GA. ( 1962). Respiration of the iris bulb in relation to the temperature and growth of the primordia. Acta Bot Neerl 11:331-410.

17. Kahane R, Vialle-Guerin E, Boukema I, Tzanoudakis D, Bellamy C,Chamaux C, Kik C. (2001). Changes in non-structural carbohydrate composition during bulbing in sweet and highsolid onions in field experiments. Environ Exp Bot 45:73-83.

18. Kukanoor, L. (2005). Post harvest studies in onion. PhD Thesis submitted to the University of Agricultural Sciences, Dharwad. http://etd.uasd.edu/ft/th8441.pdf (accessed April 18, 2011).

19. Milenkovic, I.Z., L. M. Djurovka and R. Trajkovic. (2009). The effect of long term storage on quality attributes and storage potentials of different onion cultivars. Acta Hort., (ISHS) 830: 635-642.

20. Mogren LM, Olsson ME, Gertsson UE. (2007). Quercetin content in stored onions (Allium cepa L.): effects of storage conditions, cultivar, lifting time and nitrogen fertiliser level. J Sci Food Agric 87:1595-1602.

21. Miedema P. (1994). Bulb dormancy in onion. I The Effects of Temperature and Cultivar on Sprouting and Rooting. J Hortic Sci 69:29-39.

22. Rutherford PP, Whittle R. (1982). The carbohydrate composition of onions during long term cold storage. J Hortic Sci 57:349-356.

23. Randle WM, Bussard ML. (1993). Pungency and sugars of short-day onions as affected by sulfur nutrition. J Am Soc Hortic Sci 118(6):766-770.

24. Sharma K, Assefa AD, Kima S, Koa E, Parka SW. (2014). Change in chemical composition of onion (Allium cepa L. cv. Sunpower) during post-storage under ambiente conditions. New Zeal J Crop HortSci 42:87-98. 
25. Sharma K, Assefa AD, Ko EY, Lee ET, Park SW. (2015). Quantitative analysis of flavonoids, sugars, phenylalanine and tryptophan in onion scales during storage under ambient conditions. J Food Sci Technol 52:2157-2165.

26. Salamal AM, Hicks JR, Nock JF. (1990). Sugar and organic acid changes in stored onion bulbs treated with maleic hydrazide. Hortscience 25:1625-1628.

27. Takahama U, Hirota S .(2000). Deglucosidation of quercetin glucosides to the aglycone and formation of antifungal agents by peroxidase dependent oxidation of quercetin on browning of onion scales. Plant Cell Physiol 41:1021-1029.

28. Uddin M, MacTavish HS. (2003). Controlled atmosphere and regular storage-induced changes in S-alk(en)yl cysteine sulphoxides and allinase activity in onion bulbs(AlliumcepaL. cv.Hysam). Postharvest Biol Technol 28:239-245.

29. Ward CM. (1976). The influence of temperature on weight loss from stored onion bulbs due to desiccation, respiration and sprouting. Ann Appl Biol 83:149-155.

30. Yasin HJ, Bufler G. (2007). Dormancy and sprouting in onion (Allium cepa L.) bulbs. I. Changes in carbohydrate metabolism. J Hort Sci Biotech 82:89-96. 